\title{
Raman Spectroscopy Evidence of 1:1:1 Complex Formation during Dissolution of WO3
} in a Melt of K2S2O7: K2SO4

\author{
Berg, Rolf W.; Ferré, Irene Maijó; Schäffer, Susan Jeanne Cline
}

Published in:

Vibrational Spectroscopy

Link to article, DOI:

10.1016/j.vibspec.2006.05.021

Publication date:

2006

Document Version

Publisher's PDF, also known as Version of record

Link back to DTU Orbit

Citation (APA):

Berg, R. W., Ferré, I. M., \& Schäffer, S. J. C. (2006). Raman Spectroscopy Evidence of 1:1:1 Complex Formation during Dissolution of WO3 in a Melt of K2S2O7: K2SO4. Vibrational Spectroscopy, 42(2), 346-352. https://doi.org/10.1016/j.vibspec.2006.05.021

\section{General rights}

Copyright and moral rights for the publications made accessible in the public portal are retained by the authors and/or other copyright owners and it is a condition of accessing publications that users recognise and abide by the legal requirements associated with these rights.

- Users may download and print one copy of any publication from the public portal for the purpose of private study or research.

- You may not further distribute the material or use it for any profit-making activity or commercial gain

- You may freely distribute the URL identifying the publication in the public portal 


\title{
Raman spectroscopy evidence of 1:1:1 complex formation during dissolution of $\mathrm{WO}_{3}$ in a melt of $\mathrm{K}_{2} \mathrm{~S}_{2} \mathrm{O}_{7}: \mathrm{K}_{2} \mathrm{SO}_{4}$
}

\author{
Rolf W. Berg ${ }^{a, *}$, Irene Maijó Ferré ${ }^{\mathrm{a}, \mathrm{b}}$, Susan J. Cline Schäffer ${ }^{\mathrm{a}}$ \\ ${ }^{a}$ Department of Chemistry, The Technical University of Denmark, Kemitorvet, Building 207, DK-2800 Lyngby, Denmark \\ ${ }^{\mathrm{b}}$ Facultat de Química, University of Rovira i Virgili, Tarragona 43007, Spain
}

Available online 21 June 2006

\begin{abstract}
Highly inert yellow solid $\mathrm{WO}_{3}$ was found to be soluble in considerable amounts in molten $\mathrm{K}_{2} \mathrm{~S}_{2} \mathrm{O}_{7}$ at elevated temperatures $\left(\sim 650{ }^{\circ} \mathrm{C}\right)$, if only similar molar amounts of sulfates were also present. The dissolution reaction of $\mathrm{WO}_{3}$ into a melt consisting of a 1:1 molar mixture of $\mathrm{K}_{2} \mathrm{~S}_{2} \mathrm{O}_{7}$ and $\mathrm{K}_{2} \mathrm{SO}_{4}$ was studied in detail, and Raman spectroscopy was used to characterize the products. In combination with single crystal X-ray crystal structure determination, it was shown that a new dimeric compound, $\mathrm{K}_{8}\left[\left\{\mathrm{~W}^{\mathrm{VI}} \mathrm{O}_{2}\left(\mathrm{SO}_{4}\right)_{2}\right\}_{2}\left(\mu-\mathrm{SO}_{4}\right)_{2}\right]$, was formed and its assigned Raman spectrum at room temperature is given. The $\mathrm{WO}_{2}{ }^{2+}$ cores of the dimeric complex have their symmetrical and antisymmetrical stretching modes $v_{1}\left(\mathrm{WO}_{2}{ }^{2+}\right)$ and $v_{3}\left(\mathrm{WO}_{2}{ }^{2+}\right)$ at around 1054 (strong) and 1042 (weak), and the bending mode $v_{2}\left(\mathrm{WO}_{2}{ }^{2+}\right)$ at around 292 (medium intensity), respectively (positions given in $\mathrm{cm}^{-1}$ ).
\end{abstract}

(C) 2006 Elsevier B.V. All rights reserved.

Keywords: Assignment; Dissolution; $\mathrm{K}_{2} \mathrm{SO}_{4} ; \mathrm{K}_{2} \mathrm{~S}_{2} \mathrm{O}_{7} ; \mathrm{K}_{8}\left[\left\{\mathrm{~W}^{\mathrm{VI}} \mathrm{O}_{2}\left(\mathrm{SO}_{4}\right)_{2}\right\}_{2}\left(\mu-\mathrm{SO}_{4}\right)_{2}\right]$; Melt; Raman; Solid; Spectroscopy; Tungsten oxide; WO 3

\section{Introduction}

Previously we have studied the dissolution properties of a number of oxide salts in disulfate (pyrosulfate) salt melts. In one case, $\mathrm{Nb}_{2} \mathrm{O}_{5}$ was found to dissolve in considerable amounts into molten $\mathrm{K}_{2} \mathrm{~S}_{2} \mathrm{O}_{7}$ at about $450{ }^{\circ} \mathrm{C}[1,2]$. The stoichiometric properties of this and similar reactions were studied by Raman spectroscopy [3] and X-ray single crystal diffraction [4]. Other oxide salts, e.g. $\mathrm{ZnO}$ [5] and $\mathrm{MoO}_{3}$ [6], were recently found to dissolve into $\mathrm{Na}_{2} \mathrm{~S}_{2} \mathrm{O}_{7}$ and $\mathrm{K}_{2} \mathrm{~S}_{2} \mathrm{O}_{7}$, and references to more systems are described there.

In this communication, we report results on tungsten oxide, $\mathrm{WO}_{3}$. This oxide is known as a highly inert yellow solid compound that is practically insoluble in acids. This insolubility, combined with other properties, makes tungsten oxide itself and mixtures with other metal oxides commonly used catalysts or supported catalyst surfaces, see e.g. [7].

Recently we confirmed that $\mathrm{WO}_{3}$ is sparingly soluble in acidic melts of $\mathrm{K}_{2} \mathrm{~S}_{2} \mathrm{O}_{7}$, but, surprisingly, we also discovered

\footnotetext{
* Corresponding author. Fax: +45 45252412.

E-mail addresses: rwb@kemi.dtu.dk (R.W. Berg),

irene.maijo@estudiants.urv.es (I.M. Ferré), ss@kemi.dtu.dk (S.J.C. Schäffer).
}

[8] that considerable amounts of $\mathrm{WO}_{3}$ did dissolve in into melts of $\mathrm{K}_{2} \mathrm{~S}_{2} \mathrm{O}_{7}$ at elevated temperatures $\left(\sim 650^{\circ} \mathrm{C}\right)$ if similar amounts of sulfates (or possibly potassium oxide and $\mathrm{SO}_{3}$ ) were also present. The purpose of the present project, therefore, was to use Raman spectroscopy to characterize the products formed by mixing $\mathrm{WO}_{3}, \mathrm{~K}_{2} \mathrm{SO}_{4}$ and $\mathrm{K}_{2} \mathrm{~S}_{2} \mathrm{O}_{7}$ in varying molar amounts in sealed ampoules, and then to study the range of stability of the products.

In the following, we will interpret the Raman spectra of the molten solutions to show that a $1: 1: 1$ reaction:

$\mathrm{WO}_{3}+\mathrm{K}_{2} \mathrm{SO}_{4}+\mathrm{K}_{2} \mathrm{~S}_{2} \mathrm{O}_{7} \rightarrow$ products

took place, and that $\left[\mathrm{WO}_{2}\right]^{2+}$ ions solvated by $\mathrm{SO}_{4}{ }^{2-}$ ions are formed. The stoichiometry of the reaction was determined by isolating crystals and examining them by single crystal X-ray diffraction; the results were confirmed by Raman spectroscopy.

\section{Experimental}

\subsection{Samples}

The hygroscopic $\mathrm{K}_{2} \mathrm{~S}_{2} \mathrm{O}_{7}$ [7790-62-7] was synthesized from dried $\mathrm{K}_{2} \mathrm{~S}_{2} \mathrm{O}_{8}$ salt [7727-21-1] (Merck, pro analysi $>99 \%$ ) by thermal decomposition at $250{ }^{\circ} \mathrm{C}$ for $1 \mathrm{~h}$ under a dry nitrogen 
Table 1

Relative molar compositions studied by Raman spectroscopy

\begin{tabular}{rcc}
\hline $\mathrm{WO}_{3}(\mathrm{~mol} \%)$ & $\mathrm{K}_{2} \mathrm{SO}_{4}(\mathrm{~mol} \%)$ & $\mathrm{K}_{2} \mathrm{~S}_{2} \mathrm{O}_{7}(\mathrm{~mol} \%)$ \\
\hline 0.0 & 0.0 & 100.0 \\
3.0 & 3.0 & 94.0 \\
7.0 & 7.0 & 86.0 \\
10.0 & 10.0 & 80.0 \\
13.0 & 13.0 & 74.0 \\
17.0 & 17.0 & 66.0 \\
18.0 & 18.0 & 64.0 \\
19.0 & 19.0 & 62.0 \\
21.0 & 21.0 & 58.0 \\
27.0 & 27.0 & 46.0 \\
29.0 & 29.0 & 42.0 \\
33.0 & 33.0 & 34.0 \\
\hline
\end{tabular}

atmosphere [9]. The anhydrous product was immediately transferred to an air-filled dry box (the hygroscopic $\mathrm{K}_{2} \mathrm{~S}_{2} \mathrm{O}_{7}$ requires handling in a dry box to avoid that it picks up water) [9]. In the box weighed amounts of $\mathrm{WO}_{3}$ (tungsten (VI) oxide [1314-35-8], Merck, reinst $>99 \%$ ) and $\mathrm{K}_{2} \mathrm{SO}_{4}$ ([7778-80-5], Merck, suprapur $>99.999 \%$ ), were mixed with $\mathrm{K}_{2} \mathrm{~S}_{2} \mathrm{O}_{7}$ in varying molar amounts. The mixtures were introduced into cylindrical quartz ampoules that were subsequently removed from the dry box and immediately sealed under vacuum. The relative molar compositions are given in Table 1. A composition triangle diagram is shown in Fig. 1. The ampoules were heated for a few hours in a rocking furnace at $\sim 650{ }^{\circ} \mathrm{C}$, a temperature high enough for liquids to form (the m.p. of $\mathrm{K}_{2} \mathrm{~S}_{2} \mathrm{O}_{7}$ is $419^{\circ} \mathrm{C}$ [10]). The appearance of three samples after reaction is shown in Fig. 2.

\subsection{Raman equipment}

Raman spectra were obtained by use of a DILOR-XY $800 \mathrm{~mm}$ focal-length multi-channel spectrometer with macroand micro-entrances (see Fig. 3). Excitation was done with filtered $\mathrm{Ar}^{+}$-ion laser light (wavelength $514.5 \mathrm{~nm}$, power

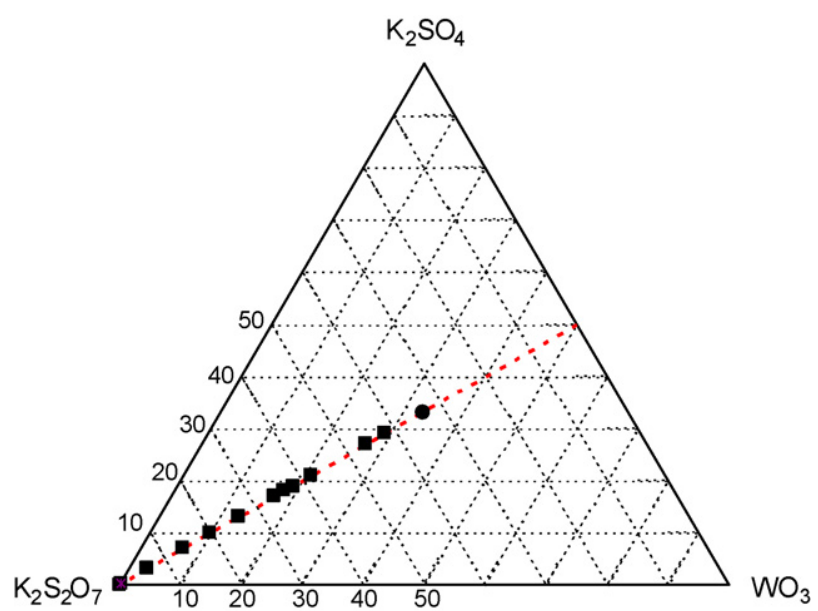

Fig. 1. Ternary composition diagram. Molar percentages of the two reactants $\left(\mathrm{WO}_{3}\right.$ and $\mathrm{K}_{2} \mathrm{SO}_{4}$ ) are given along the axes as denoted. The solid circle in the middle corresponds to the dimeric compound $\mathrm{K}_{8}\left[\left\{\mathrm{~W}^{\mathrm{VI}} \mathrm{O}_{2}\left(\mathrm{SO}_{4}\right)_{2}\right\}_{2}\left(\mu-\mathrm{SO}_{4}\right)_{2}\right]$.

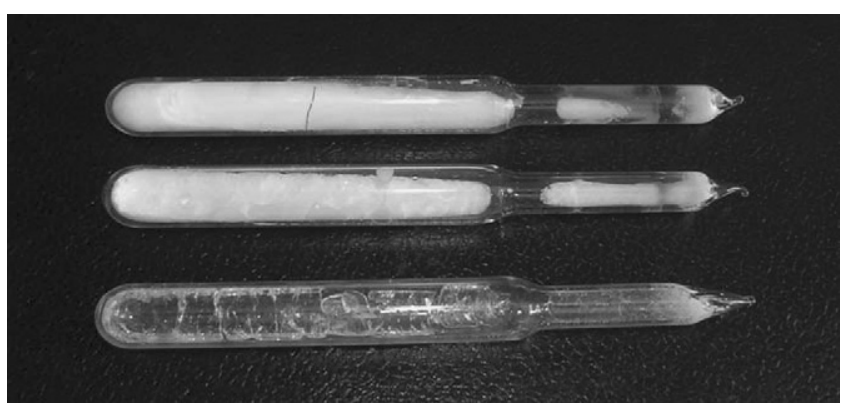

Fig. 2. Three samples (frozen melts) in ampoules at $25^{\circ} \mathrm{C}$ are shown; at the top: $3 \% \quad \mathrm{WO}_{3}+3 \% \quad \mathrm{~K}_{2} \mathrm{SO}_{4}$; in the middle: $17 \%+17 \%$; at the bottom: $29 \%$ $\mathrm{WO}_{3}+29 \% \mathrm{~K}_{2} \mathrm{SO}_{4}$ (in $\mathrm{K}_{2} \mathrm{~S}_{2} \mathrm{O}_{7}$ on mole basis).

$\sim 400 \mathrm{~mW}$ continuously, vertical polarization obtained by suitable rotation of the half-wave plate). The horizontal macroentrance was used for the melts, and crystals were measured under the microscope. Filtration of Rayleigh scattering was done with a Kaiser holographic SuperNotch-Plus ${ }^{\mathbb{R}}$ filter or near the laser line with the double pre-monochromator. Depending on the selected grating, the Raman spectral resolution was within $2-8 \mathrm{~cm}^{-1}$. The light was detected with a liquid $\mathrm{N}_{2}$-cooled CCD detector $(140 \mathrm{~K})$ connected to a MS Windows-98 computer with the Horiba-JobinYvon LABSPEC $^{\circledR}$ software. A sheet polarization analyzer, permitting vertically $(\mathrm{V})$ or horizontally $(\mathrm{H})$ polarized light to pass, was used to obtain VV- and VH-polarized spectra of liquids. Calibration was done with cyclohexane and sulfur lines to a precision of $1 \mathrm{~cm}^{-1}[11]$.

\subsection{Heating}

Sample temperature control was achieved by means of a homemade four-window electric furnace with PID regulation, based on C/A thermocouple control, or for the case of crystals under the microscope, by a LINKAM HFS91/TP93 cryostat/ furnace stage. The temperature was determined with a Pt $100 \Omega$ resistor $\left( \pm 5^{\circ} \mathrm{C}\right)$.

\section{Results and discussion}

By inspection through the furnace windows, it was found that $\mathrm{WO}_{3}$ dissolved (reacted) in considerable amounts in molten $\mathrm{K}_{2} \mathrm{~S}_{2} \mathrm{O}_{7}+\mathrm{K}_{2} \mathrm{SO}_{4}$ mixtures to form viscous yellowish melts, especially at high temperatures. When samples were cooled slowly, the melts froze to microcrystalline lumps (for low $\mathrm{WO}_{3}$ contents) and clear glasses (for higher $\mathrm{WO}_{3}$ contents) (see Fig. 2, bottom).

Equimolar amounts of $\mathrm{K}_{2} \mathrm{~S}_{2} \mathrm{O}_{7}, \mathrm{~K}_{2} \mathrm{SO}_{4}$ and $\mathrm{WO}_{3}$ gave clear homogeneous glass masses of gross formulae $\mathrm{K}_{4}\left(\mathrm{WO}_{2}\right)\left(\mathrm{SO}_{4}\right)_{3}$. No chemical analysis was made, since the compositions were already known and the melts were homogeneous. No attack on the quartz wall was seen even after prolonged heating.

Crystals were grown by quenching the melts, partly remelting them and then cooling at a rate of $6{ }^{\circ} \mathrm{C}$ per hour, allowing for better crystallization. The ampoules were studied directly or, for crystallographic examination, broken and the 


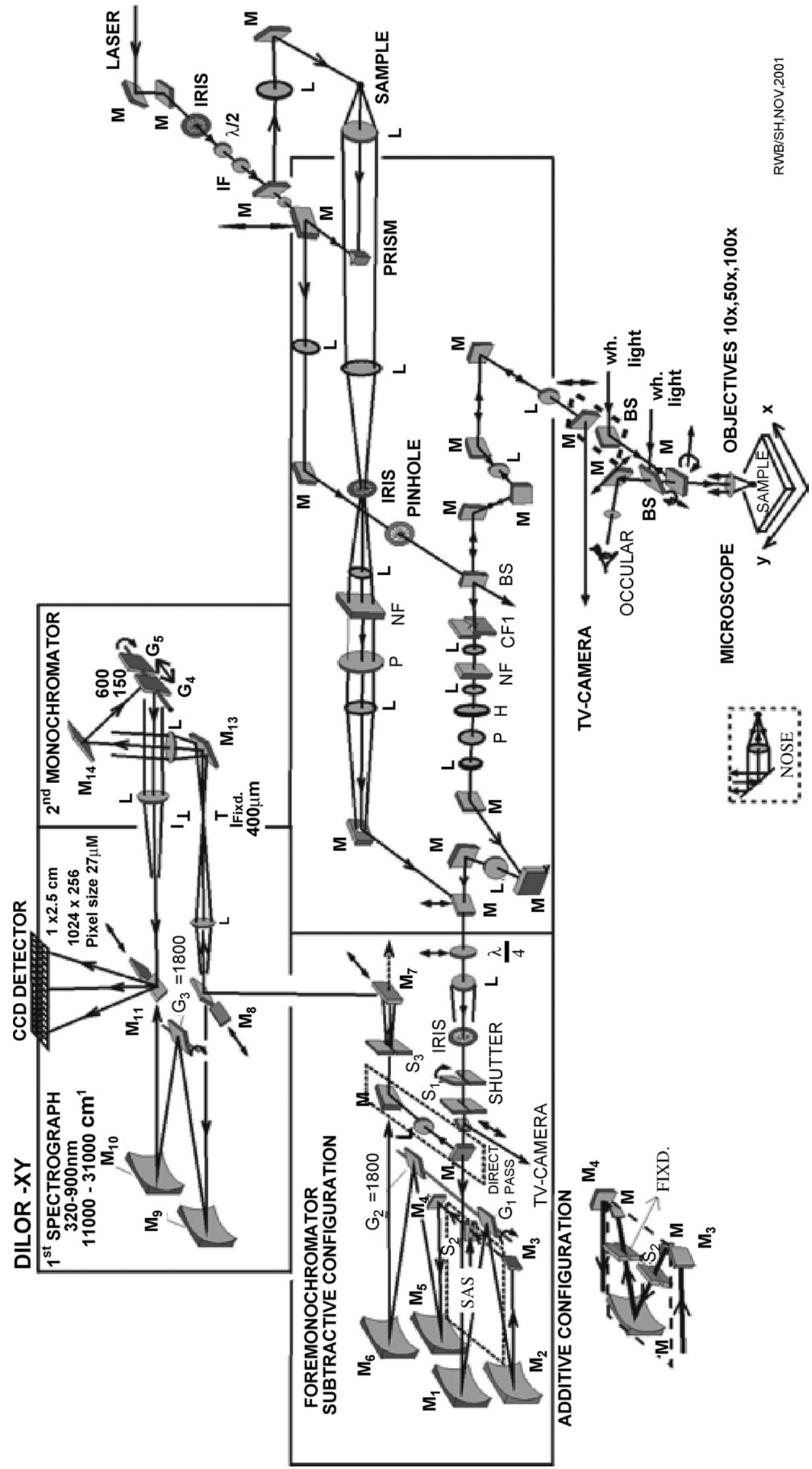

Fig. 3. Schematics of the Raman DILOR-XY spectrometer. M, mirror; $\lambda / 2$, half-wave plate; IF, interference filter; L, lens; NF, notch filter; P, polarizer; G, grating. The furnace was mounted on a XYZ-table (not shown), allowing the melts to be placed at the sample position to the right. 


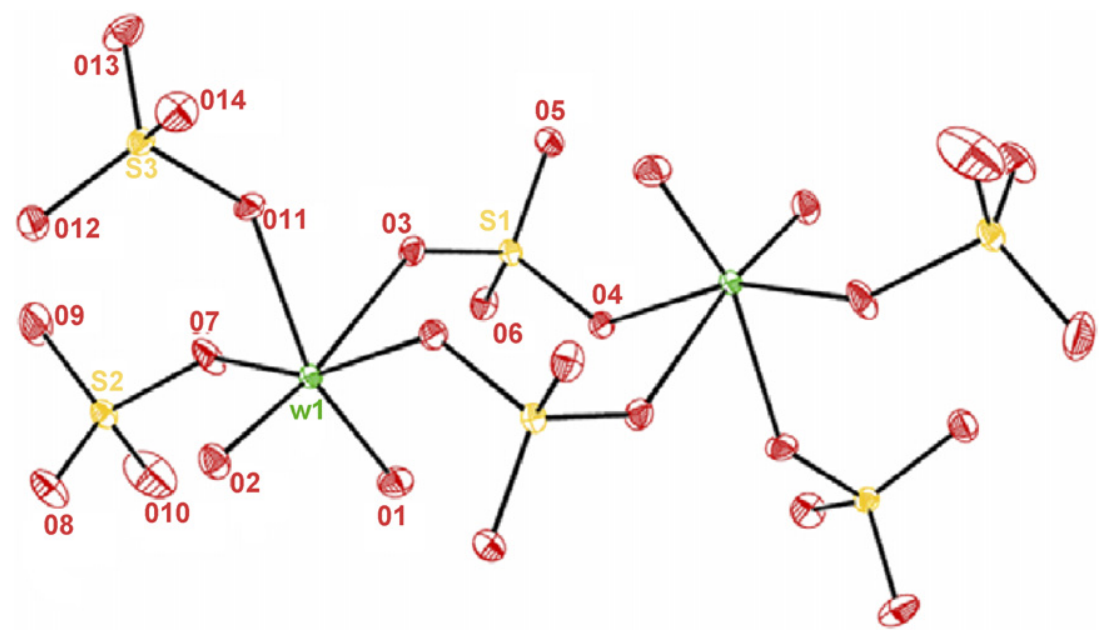

Fig. 4. Plot of the $\left[\left\{\mathrm{W}^{\mathrm{VI}} \mathrm{O}_{2}\left(\mathrm{SO}_{4}\right)_{2}\right\}_{2}\left(\mu-\mathrm{SO}_{4}\right)_{2}\right]^{8-}$ anion, showing $50 \%$ probability ellipsoids. The eight $\mathrm{K}^{+}$ions have been omitted for clarity.

colorless crystals taken out at ambient temperature. They proved to be quite stable in ordinary air. Single crystals of a compound, made from $1 \mathrm{WO}_{3}: 1 \mathrm{~K}_{2} \mathrm{~S}_{2} \mathrm{O}_{7}: 1 \mathrm{~K}_{2} \mathrm{SO}_{4}$, have recently been obtained, and the $\mathrm{X}$-ray structures of a couple of crystals solved [8] to show that the dimeric compound, $\mathrm{K}_{8}\left[\left\{\mathrm{~W}^{\mathrm{VI}} \mathrm{O}_{2}(-\right.\right.$ $\left.\left.\left.\mathrm{SO}_{4}\right)_{2}\right\}_{2}\left(\mu-\mathrm{SO}_{4}\right)_{2}\right]$, is formed. The structure is shown in Fig. 4. The compound crystallizes in the monoclinic space group $P 2_{1} / n$ with two dimeric units in the unit cell of dimensions $a=9.4362 \AA, b=13.9625 \AA, c=10.1948 \AA$, and $\beta=90.780^{\circ}$ [8].

The $\left(\mu-\mathrm{SO}_{4}\right)_{2}$ way of linking of two $\mathrm{MO}_{2}{ }^{2+}$ centers (see Fig. $4, \mathrm{M}=$ metal) has previously been found for molybdenum, where polymeric strands occurred by repetition of the linking in the $\mathrm{K}_{2} \mathrm{MoO}_{2}\left(\mathrm{SO}_{4}\right)_{2}$ structure [6]. Here in the Mo-containing melts, bands assignable to $v_{1}\left(\mathrm{C}_{2 v}\right)$ in bridging sulfato groups were seen at $958 \mathrm{~cm}^{-1}$ [6]. The W(VI) coordination sphere [8] shown in Fig. 4 is generated by inversion symmetry from the independent $\left[\mathrm{W}(\mathrm{VI}) \mathrm{O}_{2}\left(\mathrm{SO}_{4}\right)_{3}\right]^{4+}$ moiety, resulting in two bridging sulfato ligands.

During this work, by varying the composition of the melt (Table 1) and isolating crystals, it was shown that the dimeric

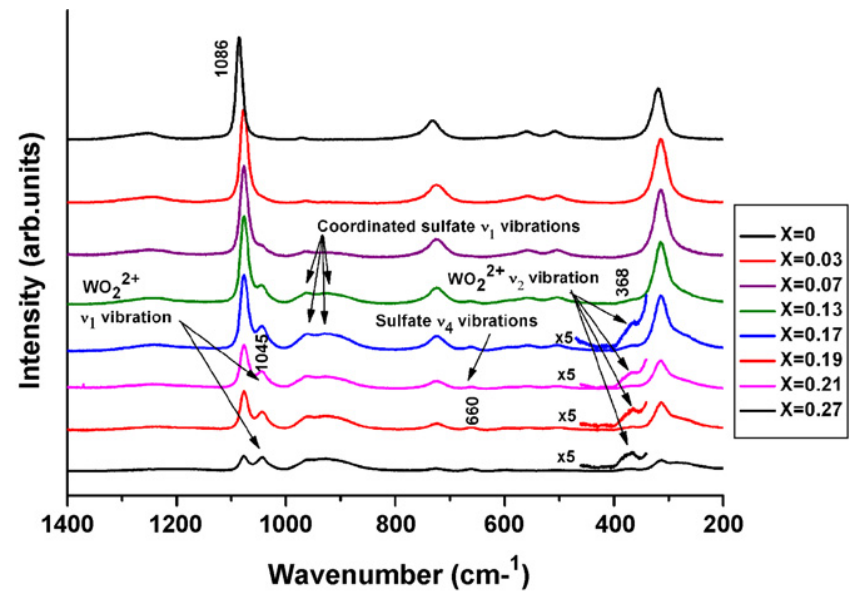

Fig. 5. Raman spectra of melts of different compositions $(X=$ formal mole fraction of $\mathrm{WO}_{3}$ and $\mathrm{K}_{2} \mathrm{~S}_{2} \mathrm{O}_{7}$ in the $\mathrm{WO}_{3}-\mathrm{K}_{2} \mathrm{SO}_{4}-\mathrm{K}_{2} \mathrm{~S}_{2} \mathrm{O}_{7}$ system) at $\sim 650{ }^{\circ} \mathrm{C}$ (spectra shifted in $y$-axis for clarity). compound $\mathrm{K}_{8}\left[\left\{\mathrm{~W}^{\mathrm{VI}} \mathrm{O}_{2}\left(\mathrm{SO}_{4}\right)_{2}\right\}_{2}\left(\mu-\mathrm{SO}_{4}\right)_{2}\right]$ exists from at least 5 to $29 \mathrm{~mol} \%$ (see Fig. 1). Melting of the $\mathrm{K}_{8}\left[\left\{\mathrm{~W}^{\mathrm{VI}} \mathrm{O}_{2}\left(\mathrm{SO}_{4}\right)_{2}\right\}_{2}(\mu\right.$ $\left.\left.\mathrm{SO}_{4}\right)_{2}\right]$ crystals started at about $600{ }^{\circ} \mathrm{C}$ (visual observation).

\subsection{Vibrational spectra}

Raman spectra of melts at $\sim 650{ }^{\circ} \mathrm{C}$ and frozen solutions at $\sim 25^{\circ} \mathrm{C}$ are shown in Figs. 5-8 ( $X=$ formal mole fraction of $\mathrm{WO}_{3}$ and $\mathrm{K}_{2} \mathrm{SO}_{4}$ in the $\mathrm{WO}_{3}-\mathrm{K}_{2} \mathrm{SO}_{4}-\mathrm{K}_{2} \mathrm{~S}_{2} \mathrm{O}_{7}$ system, see Table 1).

The spectra of melts of different compositions (see Fig. 5) showed that the characteristic bands of $\mathrm{K}_{2} \mathrm{~S}_{2} \mathrm{O}_{7}$ gradually disappeared when the tungsten oxide content was increased. At the same time, new bands appeared monotonically, indicating that a reaction has occurred. More precisely, it was seen that the most characteristic $1086 \mathrm{~cm}^{-1}$ band of $\mathrm{K}_{2} \mathrm{~S}_{2} \mathrm{O}_{7}$ disappeared and the new $1045 \mathrm{~cm}^{-1}$ band of the mixture (the new compound)

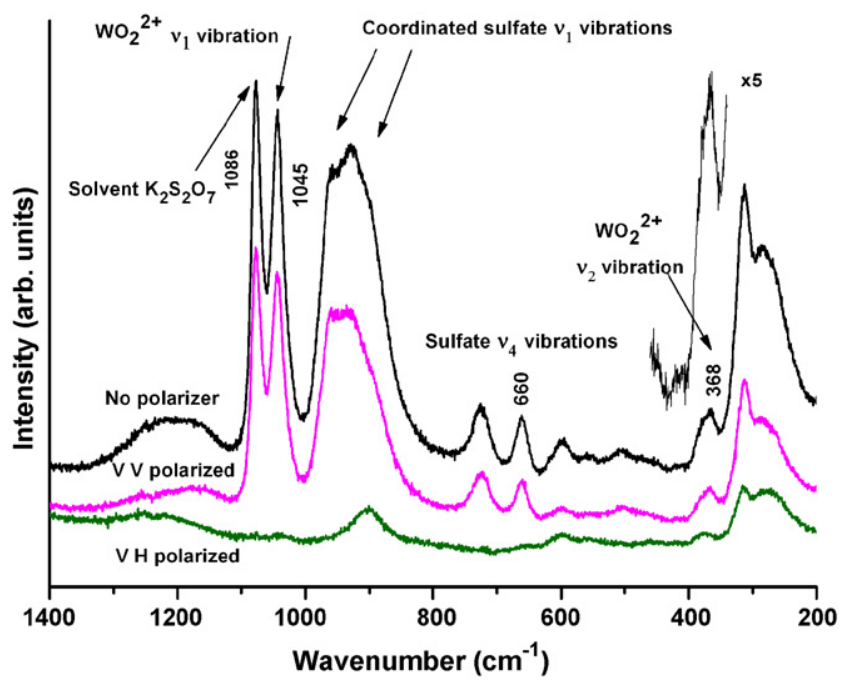

Fig. 6. Polarized Raman spectra of the melt of composition $X=0.27$ ( $X=$ formal mole fraction of $\mathrm{WO}_{3}$ and $\mathrm{K}_{2} \mathrm{SO}_{4}$ in the $\mathrm{WO}_{3}-\mathrm{K}_{2} \mathrm{SO}_{4}-\mathrm{K}_{2} \mathrm{~S}_{2} \mathrm{O}_{7}$ system) at $\sim 650{ }^{\circ} \mathrm{C}$. $\mathrm{WO}_{2}{ }^{2+}$ and $\mathrm{SO}_{4}{ }^{2-}$ stretches and $\mathrm{WO}_{2}{ }^{2+}$ bending can be assigned to bands at $\sim 1100, \sim 900$ and $\sim 390 \mathrm{~cm}^{-1}$. Other assignments are presented in Table 2. Spectra have been shifted in $y$-axis for clarity. 


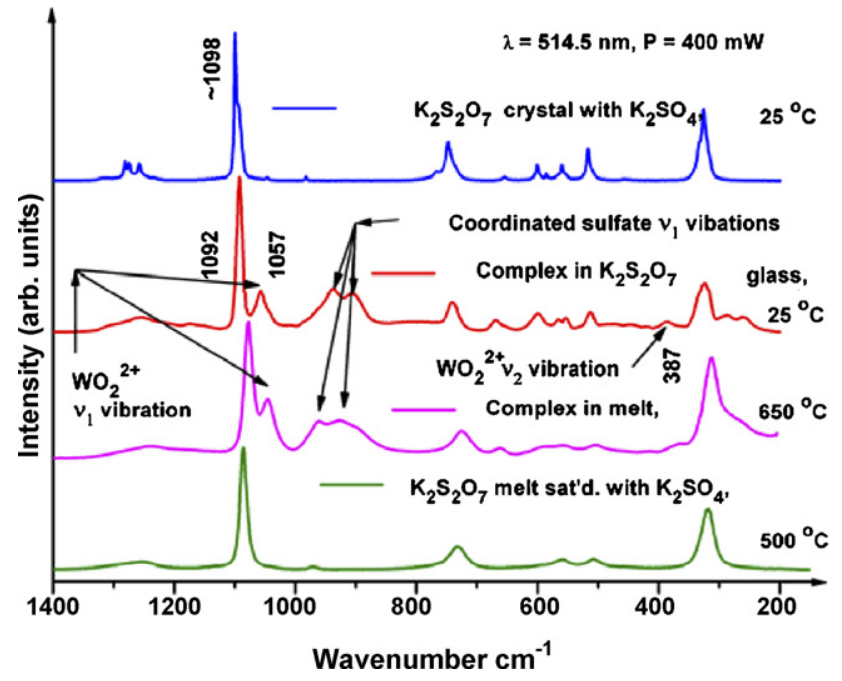

Fig. 7. Raman spectra at temperatures indicated (from below): $\mathrm{K}_{2} \mathrm{~S}_{2} \mathrm{O}_{7}$ melt saturated with $\mathrm{K}_{2} \mathrm{SO}_{4}$, complex in melt, complex in frozen glass, and frozen $\mathrm{K}_{2} \mathrm{~S}_{2} \mathrm{O}_{7}$ "solvent". $\mathrm{WO}_{2}{ }^{2+}$ and $\mathrm{SO}_{4}{ }^{2-}$ stretches and $\mathrm{WO}_{2}{ }^{2+}$ bending can be assigned to bands at $\sim 1100, \sim 900$ and $\sim 390 \mathrm{~cm}^{-1}$, depending on the temperature. Assignments are presented in Table 2. Spectra have been shifted in $y$ axis for clarity.

increased with the $\mathrm{WO}_{3}$ percentage. Even at the highest contents of tungsten oxide and sulfate (Fig. 6), we only saw indication of one kind of complex. In Fig. 6 the polarized Raman spectra of the melt of composition $X=0.27$ is shown as an example. In Fig. 7, Raman spectra are presented of a $\mathrm{K}_{2} \mathrm{~S}_{2} \mathrm{O}_{7}$ melt, saturated with $\mathrm{K}_{2} \mathrm{SO}_{4}$, of the complex in the hot melt, of the complex in a frozen glassy $\mathrm{K}_{2} \mathrm{~S}_{2} \mathrm{O}_{7}$ "solvent", and of the microcrystalline frozen $\mathrm{K}_{2} \mathrm{~S}_{2} \mathrm{O}_{7}$ "solvent".

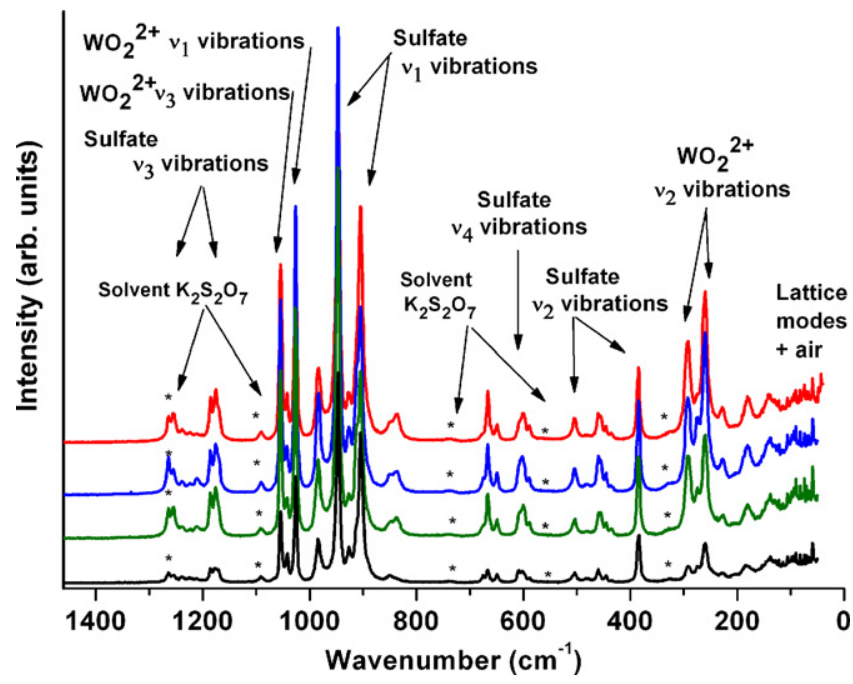

Fig. 8. Raman spectra of four $\mathrm{K}_{8}\left[\left\{\mathrm{~W}^{\mathrm{VI}} \mathrm{O}_{2}\left(\mathrm{SO}_{4}\right)_{2}\right\}_{2}\left(\mu-\mathrm{SO}_{4}\right)_{2}\right]$ crystals, measured under the microscope while still inside the ampoule. The crystals were grown at $\sim 600{ }^{\circ} \mathrm{C}$ and decanted from a $\mathrm{WO}_{3}-\mathrm{K}_{2} \mathrm{SO}_{4}-\mathrm{K}_{2} \mathrm{~S}_{2} \mathrm{O}_{7}$ melt with a formal $\mathrm{WO}_{3}$ mole fraction of 0.27 . Assignments of bands at $\sim 1100, \sim 900$ and $\sim 390 \mathrm{~cm}^{-1}$ to modes in $\mathrm{WO}_{2}{ }^{2+}$ and $\mathrm{SO}_{4}{ }^{2-}$ ions are shown (see also Table 2). Narrow lines below $\sim 150 \mathrm{~cm}^{-1}$ from surrounding air and bands likely to come from traces of $\mathrm{K}_{2} \mathrm{~S}_{2} \mathrm{O}_{7}$ (indicated with asterisks) are also seen. Spectra have been shifted in $y$-axis for clarity.

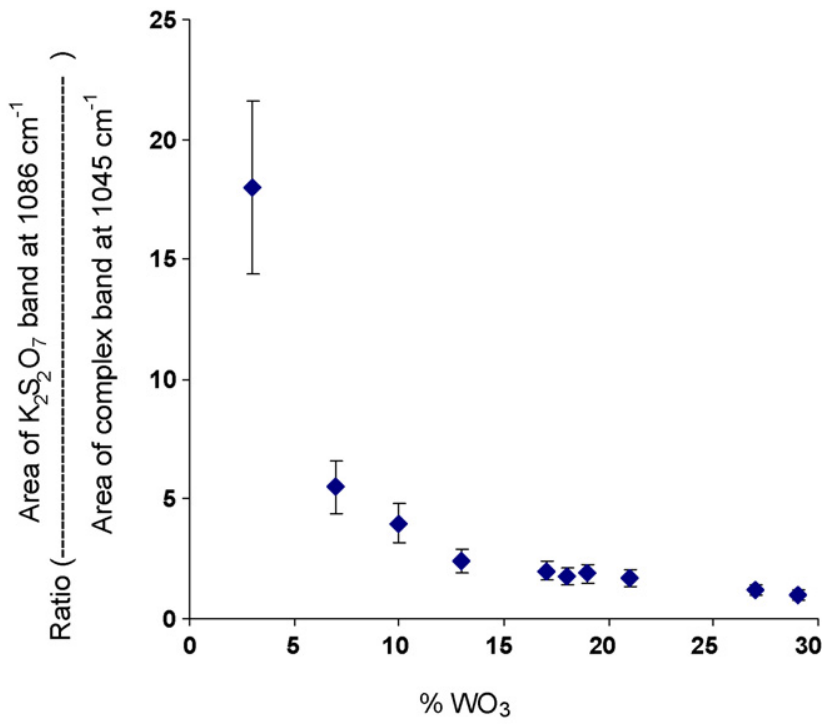

Fig. 9. Plot of the area ratios of the two bands $\left(v_{\text {disulfate }}=1086 \mathrm{~cm}^{-1}\right.$, $v_{\text {compound }}=\sim 1045 \mathrm{~cm}^{-1}$ ) vs. composition.

The reaction is accordingly interpreted as a formation of $\left[\mathrm{WO}_{2}\right]^{2+}$ ions solvated by bridging $\mathrm{SO}_{4}{ }^{2-}$ ions. In the light of the X-ray results and the similarity of the spectra in the solid and dissolved state, the stoichiometry of the reaction is represented as $1: 1: 1$, i.e. the reaction:

$$
\begin{aligned}
2 \mathrm{WO}_{3} & +2 \mathrm{~K}_{2} \mathrm{SO}_{4}+2 \mathrm{~K}_{2} \mathrm{~S}_{2} \mathrm{O}_{7} \rightarrow 8 \mathrm{~K}^{+} \\
+ & {\left[\left\{\mathrm{W}^{\mathrm{VI}} \mathrm{O}_{2}\left(\mathrm{SO}_{4}\right)_{2}\right\}_{2}\left(\mu-\mathrm{SO}_{4}\right)_{2}\right]^{8-} }
\end{aligned}
$$

Previously we have described $[1,3]$ a method to determine the stoichiometry of such reactions. When trying to use the method here, by plotting the area ratios between these two bands $\left(v_{\text {compound }}=\sim 1045 \mathrm{~cm}^{-1}, \quad v_{\text {disulfate }}=1086 \mathrm{~cm}^{-1}\right.$ above the background) versus composition (in Fig. 9) we see a decrease of the area ratio with the increase of the $\mathrm{WO}_{3}$ concentration. The curve obtained is not straight; however, it extrapolates smoothly towards the 1:1:1 reaction product, as expected from the X-ray results.

\subsection{Assignments}

The positions of the fundamental bands of a regular free $\mathrm{SO}_{4}{ }^{2-}$ ion of $T_{\mathrm{d}}$ symmetry are well known: $v_{1}=983, v_{2}=450$, $v_{3}=1105$ and $v_{4}=611 \mathrm{~cm}^{-1}$ [12]. When the symmetry of the $\mathrm{SO}_{4}{ }^{2-}$ ion is lowered by complex formation (Fig. 4), two different approximate symmetries for the sulfate ion have been found previously; $\mathrm{C}_{3 v}$ (bound unidentately) and $\mathrm{C}_{2 v}$ (bound bridged bidentately) with shifted vibrational frequencies [12]. The vibrational spectrum for the disulfate (pyrosulfate) ion is well known and well understood, based on recent ab initio calculations [13]. Therefore, the bands due to the $\mathrm{SO}_{4}{ }^{2-}$ and $\mathrm{S}_{2} \mathrm{O}_{7}{ }^{2-}$ ions can be quite definitely identified.

The free bent $\left[\mathrm{WO}_{2}\right]^{2+}$ ion has three vibrational degrees of freedom. Under the $\mathrm{C}_{2 v}$ point group symmetry, the fundamentals are expected at around: $v_{1}=972, v_{2}=300$ and $v_{3}=928 \mathrm{~cm}^{-1}$. 
Table 2

Observed Raman bands at $\sim 600{ }^{\circ} \mathrm{C}$ (in $\mathrm{cm}^{-1}$ ) and tentative assignments to fundamental group vibrations ${ }^{\mathrm{a}}$

\begin{tabular}{|c|c|c|c|c|c|}
\hline $\begin{array}{l}\mathrm{K}_{2} \mathrm{~S}_{2} \mathrm{O}_{7} \text { melt saturated with } \\
\mathrm{K}_{2} \mathrm{SO}_{4} \text { at } 500{ }^{\circ} \mathrm{C} \text { (Fig. 7) }\end{array}$ & $\begin{array}{l}\text { Complex in melt at } \\
650{ }^{\circ} \mathrm{C} \text { (Figs. } 6 \text { and } 7 \text { ) }\end{array}$ & $\begin{array}{l}\mathrm{K}_{2} \mathrm{~S}_{2} \mathrm{O}_{7} \text { crystal at } \\
25^{\circ} \mathrm{C} \text { (Fig. 7) }\end{array}$ & $\begin{array}{l}\text { Complex in frozen } \\
\text { glass at } 25{ }^{\circ} \mathrm{C} \text { (Fig. 7) }\end{array}$ & $\begin{array}{l}\mathrm{K}_{8} \mathrm{~W}_{2} \mathrm{~S}_{6} \mathrm{O}_{28} \text { crystal } \\
\text { at } 25^{\circ} \mathrm{C} \text { (Fig. 8) }\end{array}$ & Tentative assignment \\
\hline$\sim 1304 \mathrm{w}, \mathrm{br}, \mathrm{dp}$ & & $1281 \mathrm{~m}$ & & $1264 \mathrm{~s}$ & $\begin{array}{l}\text { Asymmetric } \mathrm{S}-\mathrm{O} \text { stretches in } \mathrm{SO}_{4}{ }^{2-} \\
\text { and } \mathrm{S}_{2} \mathrm{O}_{7}{ }^{2-} \text { like } v_{3}\left(\mathrm{SO}_{4}{ }^{2-}\right) \text { stretches }\end{array}$ \\
\hline \multirow[t]{5}{*}{$\sim 1253 \mathrm{w}, \mathrm{br}, \mathrm{dp}$} & & $1274 \mathrm{~m}$ & $1256 \mathrm{w}, \mathrm{br}$ & $1255 \mathrm{~s}, \mathrm{~m}$ & \\
\hline & $\sim 1240 \mathrm{w}, \mathrm{br}$ & $1257 \mathrm{~m}$ & & $1239 \mathrm{w}$ & \\
\hline & & $1231 \mathrm{w}$ & & $1224 \mathrm{w}$ & \\
\hline & & & & $1211 \mathrm{w}$ & \\
\hline & & & & $1185 \mathrm{~s}$ & \\
\hline \multirow[t]{2}{*}{$\sim 1137 \mathrm{vw}$} & & & & $1175 \mathrm{~s}$ & \\
\hline & & & $1170 \mathrm{w}, \mathrm{br}$ & $1170 \mathrm{sh}$ & \\
\hline$\sim 1085$ vs, $\mathrm{p}$ & $\sim 1086 \mathrm{~s}, \mathrm{p}$ & $\begin{array}{l}1098 \mathrm{vs} \\
1092 \mathrm{w}, \mathrm{sh}\end{array}$ & 1092 vs & $1090 \mathrm{w}, \mathrm{p}$ & $v\left(\mathrm{~S}_{2} \mathrm{O}_{7}{ }^{2-}\right)$ symmetric stretching \\
\hline \multirow[t]{9}{*}{$\sim 1045 \mathrm{~s}, \mathrm{p}$} & & $\begin{array}{l}1046 \mathrm{vw} \\
983 \mathrm{vw}\end{array}$ & & & \\
\hline & $\sim 1045 \mathrm{~s}, \mathrm{p}$ & & $1057 \mathrm{~s}$ & $\begin{array}{l}1054 \mathrm{~s} \\
1042 \mathrm{w} \\
1025 \mathrm{~s}\end{array}$ & $\begin{array}{l}v_{1}\left(\mathrm{WO}_{2}{ }^{2+}\right) \text { symmetric stretching } \\
v_{3}\left(\mathrm{WO}_{2}{ }^{2+}\right) \text { asymmetric stretching } \\
v_{1}\left(\mathrm{WO}_{2}{ }^{2+}\right) \text { symmetric stretching }\end{array}$ \\
\hline & & & $980 \mathrm{vw}, \mathrm{br}$ & $983 \mathrm{~m}$ & $\begin{array}{l}\text { Coordinated } \mathrm{SO}_{4}{ }^{2-} \text { : bridging } v_{1}\left(\mathrm{C}_{2 v}\right) \\
\text { at } \sim 950{ }^{\circ} \mathrm{C} \text { and terminal } v_{1}\left(\mathrm{C}_{3 v}\right) \\
\text { at } \sim 925{ }^{\circ} \mathrm{C}\end{array}$ \\
\hline & $\sim 958 \mathrm{~s}, \mathrm{br}, \mathrm{p}$ & & $940 \mathrm{~s}$, br & $947 \mathrm{~s}$ & \\
\hline & $\sim 928 \mathrm{~s}, \mathrm{br}, \mathrm{p}$ & & & $927 \mathrm{w}$ & \\
\hline & & & $905 \mathrm{~m}, \mathrm{br}$ & $911 \mathrm{w}, \mathrm{sh}$ & \\
\hline & $\sim 900 \mathrm{~m}, \mathrm{br}, \mathrm{dp}$ & & & $904 \mathrm{~s}$ & \\
\hline & & & & $849 w$ & \\
\hline & & & & $838 \mathrm{w}$ & \\
\hline$\sim 775 \mathrm{w}, \mathrm{br}, \mathrm{dp}$ & & $765 \mathrm{w}$ & & & $\mathrm{K}_{2} \mathrm{~S}_{2} \mathrm{O}_{7}-\mathrm{SO}_{4}{ }^{2-}$ bending \\
\hline \multirow[t]{5}{*}{$\sim 730 \mathrm{~m}, \mathrm{p}$} & $\sim 727 \mathrm{~m}, \mathrm{p}$ & $746 \mathrm{~s}$ & $740 \mathrm{~m}$ & $740 \mathrm{vw}$ & \\
\hline & $\sim 660 \mathrm{~m}, \mathrm{p}$ & & & $675 \mathrm{w}, \mathrm{sh}$ & $v_{4}\left(\mathrm{SO}_{4}{ }^{2-}\right)$ bending in complex \\
\hline & $\sim 590 \mathrm{w}, \mathrm{dp}$ & & $669 \mathrm{w}$ & $667 \mathrm{~m}$ & \\
\hline & & & & $607 \mathrm{~m}$, sh & $\mathrm{K} \mathrm{S} \mathrm{O}_{-}$and compley $\mathrm{SO}^{2-}$ and \\
\hline & & $653 \mathrm{w}$ & $655 \mathrm{vW}$ & 649 w & $\begin{array}{l}\mathrm{K}_{2} \mathrm{~S}_{2} \mathrm{O}_{7} \text { and complex } \mathrm{SO}_{4}{ }^{2-} \text { and } \\
\mathrm{S}_{2} \mathrm{O}_{7}{ }^{2-} \text { bending }\end{array}$ \\
\hline \multirow[t]{2}{*}{$\sim 599 \mathrm{w}, \mathrm{dp}$} & & $600 \mathrm{~m}$ & $600 \mathrm{~m}$ & $600 \mathrm{~m}$ & \\
\hline & & $585 \mathrm{w}$ & $565 \mathrm{w}$ & $590 \mathrm{w}$ & \\
\hline$\sim 560 \mathrm{w}, \mathrm{dp}$ & $\sim 558 \mathrm{w}, \mathrm{br}, \mathrm{p}$ & $561 \mathrm{w}$ & $554 \mathrm{w}$ & & \\
\hline \multirow[t]{2}{*}{$\sim 508 \mathrm{w}, \mathrm{p}$} & $\sim 506 \mathrm{w}, \mathrm{dp}$ & $517 \mathrm{~m}$ & $512 \mathrm{~m}$ & $504 \mathrm{w}$ & \\
\hline & & & & $481 \mathrm{vw}$ & Complex \\
\hline \multirow[t]{5}{*}{$\sim 450 \mathrm{vw}$} & & $455 \mathrm{vw}$ & & $460 \mathrm{w}$ & $\mathrm{K}_{2} \mathrm{~S}_{2} \mathrm{O}_{7}$ \\
\hline & & & & $455 \mathrm{w}$ & \\
\hline & & & & $446 \mathrm{w}$ & \\
\hline & & & & $435 \mathrm{w}$ & \\
\hline & $\sim 368 \mathrm{w}, \mathrm{dp}$ & & 387 w & $385 \mathrm{~m}$ & Complex \\
\hline \multirow[t]{6}{*}{$\sim 320 \mathrm{~m}, \mathrm{dp}$} & $\sim 313 \mathrm{~s}, \mathrm{p}$ & $326 \mathrm{~m}$ & $324 \mathrm{~m}$ & $325 \mathrm{vw}, \mathrm{br}$ & $v\left(\mathrm{~S}_{2} \mathrm{O}_{7}{ }^{2-}\right)$ bending \\
\hline & $\sim 278 \mathrm{~m}, \mathrm{br}, \mathrm{dp}$ & & $287 \mathrm{w}, \mathrm{br}$ & $292 \mathrm{~m}$ & $v_{2}\left(\mathrm{WO}_{2}{ }^{2+}\right)$ bending \\
\hline & & & $261 \mathrm{w}, \mathrm{br}$ & $274 \mathrm{w}$ & \\
\hline & & & & $260 \mathrm{~m}$ & \\
\hline & & & & $227 \mathrm{w}$ & Lattice \\
\hline & & & & $207 \mathrm{vw}, \mathrm{br}$ & \\
\hline \multirow[t]{3}{*}{$191 \mathrm{w}, \mathrm{p}$} & & & & $180 \mathrm{w}, \mathrm{br}$ & \\
\hline & & & & $139 \mathrm{w}, \mathrm{br}$ & \\
\hline & & & & $92 \mathrm{w}, \mathrm{br}$ & \\
\hline
\end{tabular}

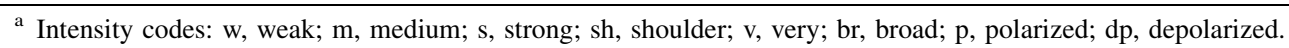

These values refer to matrix isolated $\mathrm{WO}_{2}$ molecules at low temperatures (in neon and argon gas matrix 4 and $20 \mathrm{~K}$ ) and have been obtained from analysis of electronic transition spectra with long vibrational progressions [14]. Vibrations in different $\mathrm{WO}_{3}$ polymorphous phases occur in the same range [15].

Hence, $\mathrm{WO}_{2}{ }^{2+}$ stretches and bendings should occur at about $\sim 1100, \sim 900$ and $\sim 390 \mathrm{~cm}^{-1}$. For the melts, we observed
(Table 2) the appearance of two of these bands, $v_{1}=1045$ and $v_{2}=368 \mathrm{~cm}^{-1}$, $v_{3}$ being probably weak and broad. The higher values observed here relative to the $\mathrm{WO}_{2}$ at low temperature are due to the hexavalent state of $\mathrm{W}$ in the $\left[\mathrm{WO}_{2}\right]^{2+}$ ion and to the high temperature.

This means, taking into consideration the low symmetry and the bonding between the $\mathrm{WO}_{2}{ }^{2+}$ and $\mathrm{SO}_{4}{ }^{2-}$ units in the dimeric 
$\left[\left\{\mathrm{W}^{\mathrm{VI}} \mathrm{O}_{2}\left(\mathrm{SO}_{4}\right)_{2}\right\}_{2}\left(\mu-\mathrm{SO}_{4}\right)_{2}\right]^{8-}$, that excessive mixing of group vibrations must occur. The assignments presented in Table 2 are therefore only tentative approximations.

In Fig. 8 we present Raman spectra of four $\mathrm{K}_{8}\left[\left\{\mathrm{~W}^{\mathrm{VI}} \mathrm{O}_{2}(-\right.\right.$ $\left.\left.\mathrm{SO}_{4}\right)_{2}\right\}_{2}\left(\mu-\mathrm{SO}_{4}\right)_{2}$ ] crystals, recorded while still inside the ampoule. The crystals were grown and decanted from a melt at $\sim 600{ }^{\circ} \mathrm{C}$ of composition $X=0.27$ ( $X=$ formal mole fraction of $\mathrm{WO}_{3}$ in the $\mathrm{WO}_{3}-\mathrm{K}_{2} \mathrm{SO}_{4}-\mathrm{K}_{2} \mathrm{~S}_{2} \mathrm{O}_{7}$ system).

Again stretching vibrations from $\mathrm{WO}_{2}{ }^{2+}$ and $\mathrm{SO}_{4}{ }^{2-}$ are assigned to bands between $\sim 1100$ and $\sim 900 \mathrm{~cm}^{-1}$. We clearly see increasing bands that we assign to coordinated sulfate: bridging $v_{1}\left(\mathrm{C}_{2 v}\right)$ at $\sim 950 \mathrm{~cm}^{-1}$ and terminal $v_{1}\left(\mathrm{C}_{3 v}\right)$ at $\sim 925 \mathrm{~cm}^{-1}$. $\mathrm{WO}_{2}{ }^{2+}$ bendings can be assigned to the bands in the range from $\sim 200$ to $\sim 400 \mathrm{~cm}^{-1}$, as presented in Table 2 .

The narrow lines seen below $150 \mathrm{~cm}^{-1}$ are rotational bands from the air surrounding the ampoule. Bands likely to be (at least partly) due to traces of the frozen $\mathrm{K}_{2} \mathrm{~S}_{2} \mathrm{O}_{7}$ solvent are indicated with asterisks in Fig. 8.

\section{Conclusion}

By means of Raman spectroscopy and X-rays work [8], it has been possible to determine and confirm the stoichiometry of the reaction as 1:1:1. We have only indication of formation of one kind of complex, the dimeric $\mathrm{K}_{8}\left[\left\{\mathrm{~W}^{\mathrm{VI}} \mathrm{O}_{2}\left(\mathrm{SO}_{4}\right)_{2}\right\}_{2}\left(\mu-\mathrm{SO}_{4}\right)_{2}\right]$ with two bridging sulfate ligands and four terminally bound sulfato groups. The complex seems to be very stable and exists as the only compound formed in the molten and solid state. It seems reasonable to describe the system in terms of the formation of rather free bent $\left[\mathrm{WO}_{2}\right]^{2+}$ ions of $\mathrm{C}_{2 \nu}$ point group symmetry with fundamentals at around: $v_{1}=1045, v_{2}=278 \mathrm{~cm}^{-1}$, and with $v_{3}$ being weak and broad at the high temperature. In the dimeric $\left[\left\{\mathrm{W}^{\mathrm{VI}} \mathrm{O}_{2}\left(\mathrm{SO}_{4}\right)_{2}\right\}_{2}\left(\mu-\mathrm{SO}_{4}\right)_{2}\right]^{8-}$ complexes, excessive mixing of these $\left[\mathrm{WO}_{2}\right]^{2+}$-group vibrations with modes in coordinated bridging and terminal sulfate $\left\{v_{1}\left(\mathrm{C}_{2 v}\right)\right.$ at $\sim 950 \mathrm{~cm}^{-1}$ and $v_{1}\left(\mathrm{C}_{3 v}\right)$ at $\sim 925 \mathrm{~cm}^{-1}$ \} must occur so the assignments presented are only tentative approximations.

\section{Acknowledgments}

The authors acknowledge Bodil Holten and Lise Lotte Berring of the Technical University of Denmark for preparative and crystallographic help. I.M. Ferré thanks the Erasmus Program of the European Union for a studentship making the visit to Denmark possible.

\section{References}

[1] S. Boghosian, F. Borup, R.W. Berg, Stoichiometry, vibrational modes and structure of molten $\mathrm{Nb}_{2} \mathrm{O}_{5}-\mathrm{K}_{2} \mathrm{~S}_{2} \mathrm{O}_{7}$ mixtures, in: Proceedings of the 11th International Symposium on Molten Salts, The Electrochemical Society, Pennington, NJ, November, (1998), pp. 536543.

[2] A. Paulsen, F. Borup, R.W. Berg, S. Boghosian, Spectroscopic study of niobium oxosulfato complexes in the $\mathrm{Nb}_{2} \mathrm{O}_{5}-\mathrm{K}_{2} \mathrm{~S}_{2} \mathrm{O}_{7}-\mathrm{K}_{2} \mathrm{SO}_{4}$ system at 450-700 ${ }^{\circ} \mathrm{C}$. Determination of complex stoichiometry by Raman spectroscopy, in: R.W. Berg, H.A. Hjuler (Eds.), Progress in Molten Salts Chemistry, vol. 1, Elsevier, 2000, pp. 393-397.

[3] S. Boghosian, R.W. Berg, Determination of stoichiometry of solutes in molten salt solvents by correlations of relative Raman band intensities, Appl. Spectrosc. 53 (1999) 565-571.

[4] F. Borup, R.W. Berg, K. Nielsen, The crystal structure of $\mathrm{K}_{7} \mathrm{Nb}\left(\mathrm{SO}_{4}\right)_{6}$ and $\mathrm{K}_{7} \mathrm{Ta}\left(\mathrm{SO}_{4}\right)_{6}$, Acta Chem. Scand. 44 (1990) 328-331.

[5] R.W. Berg, N. Thorup, The reaction between $\mathrm{ZnO}$ and molten $\mathrm{Na}_{2} \mathrm{~S}_{2} \mathrm{O}_{7}$ or $\mathrm{K}_{2} \mathrm{~S}_{2} \mathrm{O}_{7}$ forming $\mathrm{Na}_{2} \mathrm{Zn}\left(\mathrm{SO}_{4}\right)_{2}$ or $\mathrm{K}_{2} \mathrm{Zn}\left(\mathrm{SO}_{4}\right)_{2}$, studied by Raman spectroscopy and X-ray diffraction, Inorg. Chem. 44 (2005) 34853493.

[6] T. Nørbygaard, R.W. Berg, K. Nielsen, Reaction between $\mathrm{MoO}_{3}$ and molten $\mathrm{K}_{2} \mathrm{~S}_{2} \mathrm{O}_{7}$, forming $\mathrm{K}_{2} \mathrm{MoO}_{2}\left(\mathrm{SO}_{4}\right)_{2}$, studied by Raman and IR spectroscopy and $\mathrm{X}$-ray crystal structure determination, in: Proceedings of the 11th International Symposium on Molten Salts, The Electrochemical Society, Pennington, NJ, November, (1998), pp. 553-573.

[7] G. Mestl, In situ Raman spectroscopy for the characterization of MoVW mixed oxide catalysts, J. Raman Spectrosc. 33 (2002) 333-347.

[8] S.J.C. Schäffer, R.W. Berg, Potassium bis $\left(\mu\right.$-sulfato- $\left.1 \kappa \mathrm{O}: 2 \kappa \mathrm{O}^{\prime}\right)$ bis-[cisdioxido-cis-bis(sulfato- $\mathrm{OO})$ tungstate(VI)], Acta Crystallogr. E 61 (2005) i49-i51.

[9] N.H. Hansen, R. Fehrmann, N.J. Bjerrum, Complex formation in pyrosulfate melts. 1, Inorg. Chem. 21 (1982) 744-752.

[10] S.B. Rasmussen, K.M. Eriksen, G. Hatem, F. da Silva, K. Ståhl, R. Fehrmann, Conductivity, thermal measurements, X-ray investigations, and phase diagram of the $\mathrm{Na}_{2} \mathrm{~S}_{2} \mathrm{O}_{7}-\mathrm{K}_{2} \mathrm{~S}_{2} \mathrm{O}_{7}$ system, J. Phys. Chem. B 105 (2001) 2747-2752.

[11] R.L. McCreery, Calibration and validation. Raman Spectroscopy for Chemical Analysis, Chemical Analysis, vol. 157, Wiley-Interscience, 2000, pp. 251-291 (Chapter 10).

[12] K. Nakamoto, Infrared and Raman Spectra of Inorganic and Coordination Compounds. Part B: Applications in Coordination, Organometallic, and Bioinorganic Chemistry, John Wiley and Sons Inc., New York, 1997

[13] J.D. Dyekjaer, R.W. Berg, H. Johansen, Ab initio calculation of conformation and vibrational spectrum for the pyrosulfate ion, J. Phys. Chem. A 107 (2003) 5826-5830.

[14] W. Weltner Jr., D. McLeod Jr., Spectroscopy of tungsten oxide molecules in neon and argon matrices at 4 and $20 \mathrm{~K}$, J. Mol. Spectrosc. 17 (1965) 276-299.

[15] J. Gabrusenoks, A. Veispals, A. von Czarnowski, K.-H. Meiwes-Broer, Infrared and Raman spectroscopy of $\mathrm{WO}_{3}$ and $\mathrm{CdWO}_{4}$, Electrochim. Acta 46 (2001) 2229-2231. 